\title{
Patient Endurance in Sir Gawain and the Green Knight
}

\section{Corey Owen}

In Sir Gawain and the Green Knight, the question of late medieval heroism is a central one. Morton Bloomfield, for instance, has argued that "The drastic ambiguity of the hero in the later Middle Ages is perfectly revealed in Gawain and the Green Knight where the problem of the hero becomes acute." ${ }^{1}$ Like other romance protagonists, Gawain displays great martial courage. He accepts the Green Knight's challenge, battles his way through a perilous forest, and jumps to fight the Green Knight as soon as he realizes that the latter has not beheaded him. However, Gawain's opportunities to prove himself in battle are far outnumbered by the humiliations that he suffers during his adventure. Camelot's code of conduct compels him to accept the Green Knight's challenge, the narrative quickly summarizes his martial accomplishments in the forest, and the Green Knight responds with slight amusement to Gawain's aggressive challenge after the young knight must submit to a third feint of his opponent's axe. Furthermore, Gawain discovers that he has been the victim of an elaborate plot to humiliate Camelot and comes to realize that his acceptance of Lady Bertilak's girdle has been an act of cowardice. In spite of these factors which would

1 Bloomfield, "The Problem of the Hero," 33. Both Bloomfield and Burrow famously regard this absence of heroism as characteristic of late medieval literature. Bloomfield writes, "The absence of a true charismatic hero who is valiant and noble is a characteristic of most of the literature of the later Middle Ages in Western Europe," and Burrow comments, with specific reference to Ricardian England, that "The poems of the Ricardian period project an unheroic image of man"; Bloomfield, "The Problem of the Hero," 33, and Burrow, Ricardian Poetry, 94. 
seem to diminish his heroism, the Green Knight refers to Gawain as "On pe fautlest freke pat euer on fote zede" (2363). ${ }^{2}$

The Green Knight's pronouncement of Gawain's virtue suggests that the type of heroism that is required by Gawain has been, for the most part, different from that of other popular romance protagonists. While the authors and translators of Guy of Warwick and Bevis of Hampton, for example, celebrate the martial glory of their heroes, the Gawain-poet departs radically from this type of heroism by emphasizing the endurance that Gawain needs in order to complete his quest. The uniqueness of Sir Gawain and the Green Knight in this respect has been observed frequently. Many critics have described Gawain's adventure as necessitating the passivity of the protagonist. ${ }^{3}$ However, the concept of passivity is one that, in its modern sense, suggests a loss of self-determination; as the opposite of "active," "passive" implies a failure of agency, a concept that is fundamental to modern ideas of virtue and heroism. In "Sir Gawain and the Romance Hero," Jill Mann qualifies the notion of Gawain's passivity by using the phrase "passive heroism" to capture the contradictory nature of his so-called passivity. She emphasizes that this sort of heroism is voluntary, and claims that "action is always the easier option" because of the "effort that is necessary to relinquish attempts at control." "While Mann refers to the romance hero as somehow passive by nature, she aptly qualifies his passivity by suggesting that it "requires just as much energy as activity"; 5 what makes the protagonist's behaviour heroic is the volitional effort that he must expend in order to maintain his virtue. While she correctly identifies what she regards as Gawain's passivity as an act of will, 6 she contextualizes

2 Sir Gawain and the Green Knight, in Andrew and Waldron, eds., The Poems of the Pearl Manuscript, 207-300. Subsequent citations, provided parenthetically by line number in the text above, refer to this edition.

3 On Gawain's behaviour as passive, see Benson, Art and Tradition in Sir Gawain and the Green Knight, 88; Davenport, The Art of the Gawain-Poet, 182; Plummer, "Signifying the Self," 200; Hark, "Gawain's Passive Quest," passim; Nicholls, The Matter of Courtesy, 130; Mann, "Sir Gawain and the Romance Hero," passim; Putter, An Introduction to the Gawain-Poet, 76; and Boyd, "Sodomy, Misogyny, and Displacement," 86.

4 Mann, "Sir Gawain and the Romance Hero," 116.

5 Mann, "Sir Gawain and the Romance Hero," 111.

6 See also McAlindon, who carefully qualifies his application of the adjective "passive" to Gawain's adventures. McAlindon notes that the "'passive' but (in the circumstances) very exacting virtues of patient fortitude, truth, piety, and chastity" save Gawain when he is confronted by magical forces, but "when viewed in the context of medieval narrative and idealism as a whole," these virtues are more closely associated with the saint; McAlindon, "Magic, Fate, and Providence," 9. Furthermore, Aers argues that by baring his neck for the axe, "Gawain is [...] required [...] to turn himself voluntarily into a passive object"; Aers, Community, Gender, and Individual Identity, 167. 
her reading of the poem only within the boundaries of other, much earlier Arthurian romances, and she uses the "active" heroism of Beowulf as an example of the opposite to the passive sort manifested by Gawain. The heroism required of Gawain is unusual, but, as I shall argue, there is a more immediate context in which to examine it.

Gawain's quest can be perceived more accurately not as a passive one, but as a patient one, inasmuch as it is characterized by an exploration of themes specifically associated with patientia, a virtue with which the Gawain-poet shows intimate familiarity in Patience. The medieval understanding of the virtue patience is a largely neglected area of study, primarily because of the multitude of sources - Morton Bloomfield et al. list 6553 treatises on virtues and vices that appear in Western Europe between 1100 and 1500 C.E. ${ }^{7}$ — and because many crucial works either remain unedited or are available only in rare early editions. Nevertheless, by examining the contents of medieval discussions that appear to have been widely known, such as manuals composed by Thomas of Chobham, William Peraldus, Thomas Aquinas, and Lorens d'Orléans and the vernacular texts which their works inspired, one can determine thematic clusters that dominate discourses on patience: as a remedial virtue, patience opposes anger, yet as a part of the enduring aspect of the cardinal virtue fortitudo, it heals acedia; it therefore has a particularly close association with such passions as anger, fear, and despair. ${ }^{8}$ Furthermore, it consists not simply of suffering, but of doing so with a specific intentionality. For Aquinas, patient endurance is more difficult than martial aggression, which is the other aspect of fortitudo. The narrator

7 Bloomfield et al., Incipits of Latin Works on the Virtues and Vices.

8 For an extensive, but non-exhaustive, list of classical and medieval patience discussions, see Schiffhorst, "Patience Inventory." The commonplace description of patience as a species of fortitude, of which there are aggressive and enduring aspects, appears most clearly in several important medieval works, the first two of which, Thomas of Chobham's Summa de commendatione virtutum 4.2.4 (1220s) and William Peraldus's Summa virtutum ac vitiorum (c.1248), are essentially preachers' manuals and the third, Thomas Aquinas's Summa theologiae II.II.123-40 (1265-74), represents the pinnacle of scholastic enquiry. For instance, in his popular and influential Summa virtutum ac vitiorum, Peraldus justifies the six-part definition of fortitude he derives from Cicero's De inventione, Macrobius's Commentarium, and the popular twelfth-century Moralium dogma philosophorum by classifying the parts he chooses as either aggressive or enduring, and thereby recalling the doing/suffering topos (143[v] in the Paris 1512 print edition). Lorens d'Orléans transmits the concepts of aggressive and enduring fortitude to a French reading audience in the popular Somme le roi (c.1279), and, within a century, his work appears in various Middle English translations, including the Azenbite of Inwit (c.1340) and the Book of Vices and Virtues (c.1375). On the relationship between the Somme le roi, the Book of Vices and Virtues, and the Azenbite of Inwit, see Francis, ed., The Book of Vices and Virtues, ix. 
of Sir Gawain does not overtly include patience in the list of Gawain's virtues; even the virtue forsnes (646), that is, his "courage" or "fortitude," seems to suggest primarily martial fortitude, but a medieval understanding of patience as enduring fortitude, like that which is found in Patience, renders the characterization of Gawain and his adventure intelligible. ${ }^{9}$ By reading the poem in the context of the medieval patience discussions that circulated widely in the closely related penitential and virtues and vices traditions, one can discern an immediate intellectual context for the poem, one that specifically accounts for the great difficulty of the endurance that the poem depicts and the relationship between this endurance and the vivid emotional states of the protagonist. An understanding of these aspects of the virtue is essential for explaining both the reasons for Gawain's failure - an issue that the narrative invites the audience to consider - and the implications of Gawain's decision to wear the girdle as a constant reminder of his failure.

This reading aims to address several tendencies in the critical reception. The first is the notion that Gawain's behaviour can be described as passive. The second, which I shall consider only briefly, is the impulse to reduce the narrative to either its religious or its secular aspects. Joseph A. Longo and Lynn Staley Johnson, for instance, who focus on the presence of "religious" romance in the text, tend to read the courtly aspects of the text, that is, the feasting, games, and flirtation, as somehow condemned by the author, and thereby inaccurately perceive him as a rigid moralist; ${ }^{10}$ in contrast, David Aers and J. J. Anderson, who both assert the predominance of the "courtly" romance over "religious" aspects, regard the poet as a secularist and thereby fail to account satisfactorily for the close relationship between courtly and religious values. ${ }^{11}$ I shall argue that although the virtues have ultimately spiritual significance, the secular context of Sir Gawain and the Green Knight enables the poet to explore the great difficulty of enduring fortitude, of patience, while maintaining the heroism of his protagonist. Gawain fails by succumbing to the fear of death because his passions

9 While "enduring fortitude" implies "patience" as well as a cluster of related virtues, in Patience, the Gawain-poet shows his understanding of patience literature in particular, which typically characterizes the virtue as a part of enduring fortitude. Thus, I use "patient fortitude" to emphasize the close association of these virtues in the thought of the Gawain-poet and to highlight their distinction from aggressive or martial fortitude.

10 See Longo, "Sir Gawain and the Green Knight: The Christian Quest for Perfection," passim; and Johnson, The Voice of the Gawain-Poet, 37-96.

11 See Aers, Community, Gender, and Individual Identity, passim, and Anderson, "The Three Judgments and the Ethos of Chivalry." 
are upset by the hope of survival; hope is here not the theological virtue but a passion that Aquinas discusses in the context of enduring fortitude, and the girdle becomes an emblem of the failure of patience. Thus, I shall argue that the Gawain-poet dramatizes the belief that patience is more difficult than aggression, an opinion that Aquinas articulates in great detail and that goes beyond the idea that endurance in Sir Gawain requires just as much energy as aggression. ${ }^{12} \mathrm{~A}$. C. Spearing, for instance, expresses this oddly apologetic approach to explaining the courage that Gawain needs in order to complete his adventure: "the action demanded of [Gawain] in confronting the monstrous Green Knight is approximately the same as that demanded of Beowulf in facing his monsters, or of Arthur in facing the Giant of St Michael's Mount."13 Gawain, however, fails exactly because he is asked for more than that which is required of Beowulf or Arthur. Thus, Sir Gawain and the Green Knight expands the concept of knightly fortitude from courage in battle, which is rather mundane for a martial protagonist, to an acceptance of the likelihood of death in circumstances of ambiguous seriousness, a test of enduring fortitude that reveals the power of the will in the face of powerlessness and suffering, and one that provides much potential for dramatic struggle and character development.

\section{Patient Endurance}

Patience is not mentioned explicitly in the poem's presentation of Gawain's virtues. The symbol of the pentangle points to the interconnectedness of the virtues, a truth that is reflected in Gawain's accusing himself of cowardice and covetousness and in

12 While I do not wish to assert that the Gawain-poet was familiar with Aquinas's work on moral theology, the possibility cannot be discounted. For instance, Spendal, in "The Fifth Pentad," an article that Andrew and Waldron cite in their edition (11. 651-55n.), detects the influence of Aquinas's list of the five parts of justice on the list of Gawain's five virtues. Aquinas's Secunda secundae appears eight times in Benedictine catalogues and once in the friars' catalogues; see Sharpe et al., English Benedictine Libraries, 886, and Humphreys, The Friars' Libraries, 275. It is mentioned just as often as, and sometimes more frequently than, other popular texts on the virtues and vices. For instance, Sharpe et al. list only two copies of Peraldus's Summa de vitiis et virtutibus appearing in Benedictine catalogues, and Humphreys lists six copies of the Summa de virtutibus and five of De vitiis et virtutibus in catalogues from the friars' libraries; see Sharpe et al., English Benedictine Libraries, 891, and Humphreys, The Friars' Libraries, 278. In addition, Sharpe et al. list thirteen copies of Chobham's Summa confessorum reported at the Abbey of the Blessed Virgin Mary in York, and Bell lists one instance at the Premonstratensian Abbey of St Radegund, Bradsole, Kent; see Sharpe et al., English Benedictine Libraries, 886, and Bell, The Libraries of the Cistercians . . and Premonstratensians, 315.

13 Spearing, The Gawain-Poet: A Critical Study, 184. 
his subsequent fall into anger and discourtesy in his diatribe against women. Gawain is faultless in his five wits, ${ }^{14}$ has never failed in the works of his hands, ${ }^{15}$ and puts his trust, his afyaunce, in the five wounds of Christ, a symbolic act that expresses the knight's faith in a manner that also suggests his secular allegiance. He derives his forsnes from the five joys of the Virgin Mary (640-47) who functions in lieu of the chaste knight's paramour: her image gives him courage in battle. Furthermore, he practises fraunchyse, felaßschyp, clannes, cortaysye, and pité (651-54), all of which are tested to varying degrees during the narrative. ${ }^{16}$ His afyaunce and forsnes are inspired by religious symbols; while Anderson suggests that in this secular, martial context these religious items are reduced to talismans at best, ${ }^{17}$ a medieval reader whose narrative expectations were informed by the same religious sources as those that underlie the other works by the Gawain-poet would have presumed that Gawain's faith and courage would bring him success only insofar as the hero acted according to the will of God. ${ }^{18}$ Gawain's relationship to the divine is mediated by the ideal virtues that he manifests, and it is the testing of this relationship that is at the centre of Gawain's encounter with the ambiguous figure of the Green Knight at the Green Chapel. Because of the interrelation of the virtues, enduring fortitude is required so that any one of these virtues can manifest itself, but none of them directly implies endurance.

While fortitude does appear among Gawain's virtues, the term refers primarily to the aggressive sort. The fifth group of five virtues represented by the pentangle suggests the intimate relationship between chivalric and spiritual virtues, and it is here that Theodore Silverstein detects the influence, either direct or indirect, of Cicero's

14 On Gawain's “wyttez" (640) as mental powers that mediate between the senses and the intellect, see Whiteford, "Rereading Gawain's Five Wits."

15 I understand this virtue as referring to his consistent success in martial combat.

16 Fraunchyse suggests "magnanimity" and "largesse"; fela $3 s c h y p$ implies “camaraderie," which, according to Morgan, is a moral quality; Morgan points specifically to "chastity" in his interpretation of the Gawain-poet's use of clannes and to "refinement of manners" in his understanding of the poet's use of cortaysye; Morgan, "The Significance of the Pentangle Symbolism," 776 and 777. Finally, pité is understood as either "pity" or "piety." Gawain's virtues are the subject of many studies, none of which, to my knowledge, has discerned patient endurance among the five virtues of chivalry.

17 Anderson argues that "[Mary's] image is painted on the inside of [Gawain's] shield, but this is for practical reasons rather than religious ones"; Anderson, "The Three Judgments and the Ethos of Chivalry," 349.

18 See, for instance, lines 724-25, which also suggest Gawain's obedience to the will of God: "Nade he ben duzty and dryze and Dryztyn had serued, / Douteles he hade ben ded and dreped ful ofte." I shall discuss this passage in greater detail below, p. 190. 
De officiis, a work that has important implications for the relationship between fortitude and patience. ${ }^{19}$ While Silverstein discusses the presence of the Ciceronian tradition in Sir Gawain primarily through the poem's presentation of trawthe, which is, as he argues, identical to Cicero's idea of fides, he claims that Cicero's other moral virtues, including fortitude, are conspicuously absent from the list of Gawain's virtues: "[Gawain's] adventure will exemplify or test, not only the parts of justice symbolized on the shield, but also his other moral virtues as well — prudence, temperance, fortitude - though they are never specified, either on the shield or in the course of the narrative itself." ${ }^{20}$ Contrary to Silverstein's opinion, the concept of fortitude does indeed appear among his virtues: "his forsnes he fong at pe fyue joyez / Pat pe hende Heuen Quene had of hir Chylde" (646-47). Malcolm Andrew and Ronald Waldron as well as J. J. Anderson all gloss forsnes as "fortitude"; 21 the Middle English Dictionary provides two possible definitions of the word as "strength" and "forcefulness." 22 While the secondary meanings suggest aggression, the image of the Virgin Mary painted on the inside of his shield, which is to help him overcome his natural fear of suffering during battle, subtly suggests the presence of the enduring aspect of the virtue. Thus, patience, perseverance, and constancy, the three virtues that often appear clustered together in lists of the parts of the enduring aspect of fortitude, ${ }^{23}$ are only implied in the list of his virtues, and it is his capacity for patient endurance that the quest tests most rigorously, and, as I hope to show, it is this aspect of fortitude that he regards himself as lacking when he later accuses himself of cowardyse (2379). While

19 As Silverstein notes, De officiis was immensely popular in the Middle Ages, "appearing as it does everywhere in the West among florilegia and compends from the twelfth to the fifteenth centuries and after"; Silverstein, "Sir Gawain in a Dilemma," 2.

20 Silverstein, "Sir Gawain in a Dilemma," 8.

21 Andrew and Waldron, eds., The Poems of the Pearl Manuscript, 319; and Anderson, ed., Sir Gawain and the Green Knight, Pearl, Cleanness, Patience, 194n.

22 Middle English Dictionary s.v. forceness(e.

23 In scholastic discussions of the enduring aspect of the cardinal virtue fortitude, "patience" and one or more other virtues appear as parts of this virtue. Peraldus's six-part definition of fortitude includes securitas, patientia, constantia, perseverantia, magnanimitas, and fiducia. In the Summa theologiae, Aquinas's four-part model of fortitude includes magnificentia and fiducia, both of which are aggressive, and patientia and perseverantia, both of which are parts of enduring fortitude. These scholastic distinctions typically appear in vernacular texts as well. The Book of Vices and Virtues, for instance, presents a sevenfold definition of prowesse/doußtiness, which contains magnanimite, affiaunce (good hope), surete/sikernesse (confidence), pacience/suffraunce, constaunce/continuance (constancy), magnificence/gretnesse, and hunger and prist of ri3tfulhede; Francis, ed., The Book of Vices and Virtues, 164. 
the absence of the term "patience" in Sir Gawain raises understandable questions about the poet's conscious engagement with the virtue, the ethos of Patience, which examines the enduring aspect of the cardinal virtue fortitudo, characterizes the heroism that Sir Gawain is called to manifest.

Patient endurance is tested throughout the narrative, and Gawain's failure to practise perfect patience results in further lapses of virtue. Forsnes may refer primarily to the attacking aspect of fortitude, yet Gawain's accusing himself of cowardice at the end of the poem does not suggest a failure of martial fortitude, since, as the poet notes in lines 715-25, he has fought valiantly in the forest. Also, he has just leapt to defend himself against another blow by the Green Knight (2322-30). Instead, his selfaccusation originates in the recognition of a failure of endurance, which results from his inability to fortify himself against the fear of death that prompts him to accept the girdle. Although Gawain displays much fortitude throughout the narrative, when the lady offers him the opportunity to survive the Green Knight's blow, he accepts it at the cost of breaking his agreement with Bertilak concerning the exchange of winnings. When the Green Knight debriefs Gawain on his performance during the adventure, he pronounces Gawain's superiority among knights (2364-65);24 he points out that this failure is a relatively small one and thereby confirms both Gawain's heroism and the difficulty of endurance: "Bot here yow lakked a lyttel, sir, and lewté yow wonted; / Bot pat watz for no wylyde werke, ne wowyng nauper, / Bot for ze lufed your lyf - pe lasse I yow blame" (2366-68). ${ }^{25}$ According to the Green Knight's estimation, Gawain has failed merely because of his desire to live. Also, the Green Knight does not chastise Gawain for breaking the agreement to submit to a blow of his axe; after all, Gawain intends to keep the meeting throughout the narrative, and never once wavers from his intention, even though he experiences much fear. ${ }^{26}$ Rather, it is for his failure to maintain his honour in the exchange of winnings that the Green

24 "As perle bi pe quite pese is of prys more, / So is Gawayn, in god fayth, bi oper gay kny3 tez." See also the Green Knight's response to Gawain's aggression in line 2338; when Gawain springs to fight him, the Green Knight refers to the knight as "Bolde burne."

25 Although the Green Knight's disclosure of his associations with Morgan and magic, which suggests that the test is now complete, potentially draws his judgement into question, the narrator does not suggest that the Green Knight's gentle treatment of Gawain's failure is to be discounted. In order to account for the Green Knight's unclear ethics, Mann convincingly points to lines 2354-55 — "Trwe mon trwe restore / Penne par mon drede no wape" - arguing that the Green Knight's sense of trawpe "[is] a response to Gawain's"; Mann, "Sir Gawain and the Romance Hero," 116.

26 I shall return to this argument in my discussion of Gawain's passions below, pp 192-203. 
Knight slightly wounds Gawain, and this happens because of the protagonist's fear of death.

Gawain, as the pentangle knight, perceives the interconnection of the virtues. The failure of enduring fortitude, he sees, has inevitably led to other faults; in the first words he speaks after the Green Knight absolves him, he accuses himself of cowardice and covetousness: "Corsed worth cowarddyse and couetyse bope! / In yow is vylany and vyse, pat vertue disstryez" (2374-75). He again emphasizes the primacy of fortitude shortly afterwards: "For care of py knokke, cowardyse me tazt / To acorde me with couetyse, my kynde to forsake" (2379-80). Although Gawain's and the Green Knight's responses to the nature of Gawain's fortitude differ, both characters' reactions confirm the importance of this virtue with respect to the other virtues and both emphasize that Gawain's adventure was intended to test this virtue in particular. Although he has been unable to perceive it, Gawain's patient fortitude has been tested continually, even, and especially, in the apparent safety of Hautdesert. While couetyse suggests a failure of fraunchyse and, possibly, of fela zschyp, cowardyse is the opposite of forsnes, which, at the beginning, appears to be the aggressive aspect of fortitude. As I discuss below, Gawain's subsequent anger and discourteous speech about women result from the shame he experiences because of his perceived cowardice. Nevertheless, Gawain's initial and primary failure is one of endurance; the virtue that is not represented by the knight's symbol, the one that is only hinted at by the presence of the Virgin on the inside of his shield, the image that faces him alone, is the one on which Gawain's other virtues depend. Thus, the counterpart to Morgan's magic, which possibly has the power of life and death over the knight, is the Virgin's image on the inside of the shield, the image that is to remind Gawain, as Donald R. Howard puts it, of the "spiritual indifference to destiny" required by a Christian knight. ${ }^{27}$

The enduring nature of the quest and its resolution, the focus on Gawain's suffering rather than on his martial exploits, and the frequent emphases on Gawain's fear, anger, and despondency all suggest the operation of patience as a structuring principle of the narrative, even if its role is not clearly defined until the end. The marvel that precipitates Gawain's quest is the two-part challenge that the Green Knight brings. The first part consists of beheading him, and it requires a simple

27 Howard, The Three Temptations, 228. Interestingly, both Morgan and the Virgin exert their power from hidden and marginal positions within the narrative. For recent discussions of the hidden power of Morgan, see Heng, "Feminine Knots," and Twomey, "Morgan le Fay at Hautdesert." 
act of martial aggression in its purest form; at this point, at least for the protagonist, there is no defending or suffering involved. The second part, however, involves an act of absolute endurance. In lines 417-29, Gawain effortlessly beheads the knight, after which the narrative turns to Gawain's endurance as he seeks the Green Knight and prepares to receive a blow like the one he has given. The type of death that Gawain faces is analogous to the martyrdom that Aquinas describes as the ultimate exemplar of fortitude. ${ }^{28}$ Although Gawain is not facing death in order to uphold his belief in God, and is therefore not facing martyrdom in a technical sense, Gawain's decision to accept decapitation by the Green Knight is necessary in order to maintain the legitimacy of Camelot as an agent of political stability. ${ }^{29}$ The Green Knight's challenge, which is aimed at the entire court, potentially destabilizes the courtly and martial idealism that Camelot represents. ${ }^{30}$ Furthermore, if the plot were recast within the context of a purely religious test, and if Gawain were to fail, the audience's respect for him after his failing to bear witness to God with his death would be much less than it is after he rashly attempts to protect his life in the context of a game. In other words, such an examination of the difficulty of enduring fortitude could not be depicted within the context of hagiography, in which the failure to die for God automatically excludes the protagonist from receiving any compassion from the audience. ${ }^{31}$ Nevertheless, from a clerical position, which is the perspective that characterizes most of the material in Cotton Nero A.x, Gawain faces the ultimate challenge to his virtue;

28 For Aquinas, martyrdom is the essence of the enduring aspect of fortitude because a martyr relinquishes his or her life for the sake of the truth. On Aquinas's view of martyrdom and fortitude, see Summa theologiae II.II.123.5 and 6 as well as II.II.124; see also De Young, "Power Made Perfect in Weakness," 158-59. Aquinas's understanding is a Christian reversal of the Aristotelian definition of fortitude, which regards military aggression as the essential element of the virtue.

29 Aers rightly suggests that Gawain is tested for his dedication to the heroic ethos, which he reveals during his stillness as he waits for the second stroke of the Green Knight's axe: "As he stands absolutely still, rock-like, under the second stroke he shows total mastery over the fear of death, won in and through his total identification with the heroic ethos"; Aers, Community, Gender, and Individual Identity, 168. Not only does this dedication disclose a "common culture" shared by Gawain and the Green Knight, as Aers suggests in the same passage, but it also asserts the legitimacy of Camelot, of which Gawain is the representative.

30 This is contrary to Mann's contention that Gawain's submission to the axe is motivated solely by his promise to submit; see "Sir Gawain and the Romance Hero," 109. In accordance with her reading of Gawain as a passive hero, Mann disregards the testing of Camelot's worth as a motivation for Gawain's acceptance of the adventure.

31 Cp. Patience, where Jonah must be redeemed after his refusal to preach to the Ninevites. 
because anger helps one overcome fear, the acceptance of death without the possibility of retaliation is the greatest test of fortitude.

\section{From Aggression to Endurance: Necessity and Will}

The virtues associated with enduring fortitude involve embracing necessity through an act of will. As the narrator of Patience states when he is faced with the necessity of a difficult journey, "What grayped me pe grychchyng bot grame more seche?" (53). The close relationship between patience and the will is discussed in the Summa virtutum de remediis anime, a putative source for Chaucer's Parson's Tale, in which the author identifies three types of patience:

Prima est asinaria, que patitur quia oportet [...]. Secunda est mercennaria, que patitur quia expedit. [...] Tercia paciencia est uoluntaria, que patitur quia placet, que exemplo Christi "cum gaudio sustinet crucem."

$$
(4.986-1006)^{32}
$$

[The first is that of a donkey, who suffers because it is necessary [...]. The second is that of a mercenary, who suffers because it is gainful. [...] The third kind of patience is that of free will, which suffers because it pleases, and which after the example of Christ "endures the cross with joy."]

While the Gawain-poet may not have known the Summa virtutum de remediis anime at first hand, his awareness of the degrees of patience is revealed through his characterization of Jonah, who responds only to necessity, and of God, who endures sins voluntarily because of his love for humanity. In both Patience and Sir Gawain, a descent into constriction reveals the fundamental and essential potency of the self; both necessity and impasse manifest that which is not constrained by their apparent power, and the Gawain-poet uses these plot devices to depict Gawain's patient acceptance of the Green Knight's challenge.

Essentially, the virtue of patience is graduated according to the intentionality that motivates one's endurance of suffering. While Gawain is not physically constrained in the narrative, he must abide by a specific code of conduct, even when it is clear that he would rather not. According to Mann, Gawain is first subjected to this code when he intervenes before Arthur can accept the Green Knight's challenge:

32 Summa virtutum de remediis anime, ed. Wenzel, text with facing translation, 206-207. 
It may seem that Gawain is "active" at least to the extent that he chooses to take up the Green Knight's challenge, judging himself fit to meet it. But a close attention to the poem will show that this is not really the case. [...] What makes it clear is the seating-plan for dinner, which the poet has carefully outlined in the course of describing the feast. [... . Gawain has the highest place of honour after Bishop Baldwin. The bishop, being a cleric, cannot accept a knightly challenge, which means that it falls to Gawain to give the lead in extricating the king and the court from the difficult situation which has arisen. ${ }^{33}$

Mann notes an element of necessity in his position as the recipient of the adventure. While Gawain has presumably earned his position through his previous valorous deeds, he is now constrained to abide by his status and reputation, no matter how he might feel about the situation. He does not audaciously seek a quest; rather, he is chosen in much the same way as Patience's Jonah, whom God commands to travel to Nineveh: the implications of the secular code at Camelot have a subtly analogous effect on Gawain. ${ }^{34}$ However, unlike Jonah, who refuses to accept the mission that he has been given, Gawain overcomes his fear and embraces it; that he waits until after Arthur prepares to strike the Green Knight aligns his hesitancy slightly with that of Jonah, as does his acceptance of the adventure only when the inescapability of the situation is made clear, an act that risks associating his patience with that of an ass, at least according to the schema found in the Summa virtutum. Nevertheless, the manner in which Gawain embraces the adventure allows him to transcend necessity. He acts calmly and purposefully, gracefully accepting the social necessity of the situation. ${ }^{35}$ Gawain manifests

33 Mann, "Sir Gawain and the Romance Hero," 109-110.

34 The situation that Gawain faces may seem less absolute than the transcendent necessity that inspires Jonah's behaviour since the order that compels Gawain to respond to the Green Knight's challenge does not threaten to drag him physically to the Green Chapel, yet if Gawain allows the king to risk death by the Green Knight's axe, the stability of the entire kingdom is threatened, much like the ship that carries Jonah; see Patience, 1l. 137-244.

35 While Gawain's hesitation does indeed show deference to the king, he could perhaps have asked for permission to accept the challenge before the Green Knight insults Arthur and his court, and he could certainly have requested the battle before Arthur is ready to strike. I shall return to this scene below, pp 193-96, in order to discuss the connection between the emotions and patience. I thank Florilegium's anonymous reviewers for reminding me of lines 1210-16, in which Lady Bertilak flirtatiously threatens to "bynde" Gawain in his bed, who responds, "Me schal worpe at your wille and pat me wel lykez, / For I zelde me zederly a zeze after grace; / And pat is pe best, be my dome, for me byhouez nede!" Gawain's playful response highlights the themes of necessity, submission, and endurance that characterize the romance. 
his virtue not simply through his acceptance of inevitability, but through his calm and gracious, if slightly delayed, response to this unavoidable situational circumstance.

The tension between necessity and voluntary endurance continues during Gawain's search for the Green Chapel. While his journey may not be marked by the haphazard wandering that characterizes the progress of a rudderless boat, ${ }^{36}$ Gawain arrives at his destination not through his discovering it based on an informed search, but through a supernatural response to his determined journey to an unclear location; while he makes his way through a physical geography that scholars identify as fourteenth-century Staffordshire, Gawain's prayer seems to be the only act that is able to bring him to Hautdesert, the location from which he can reach his appointment. ${ }^{37}$ After he had beheaded the Green Knight, the latter assured Gawain that he would be able to find him for their scheduled meeting at the Green Chapel:

"Loke, Gawan, pou be graype to go as pou hettez

And layte as lelly til pou me, lude, fynde

As pou hatz hette in pis halle, herande pise knyztes.

Pe Kny3t of pe Grene Chapel men knowen me mony;

Forpi me for to fynde, if pou fraystez, faylez pou neuer."

(448-55)

Here, the Green Knight issued Gawain another challenge: not only must he come to the Green Chapel to receive a return blow, but he must search for the Green Knight. Nevertheless, his opponent assures him that he will be successful in his quest if he makes an effort.

The martial aspects of Gawain's journey to Hautdesert are understated, and instead, his suffering occupies the foreground. ${ }^{38}$ Gawain's battles are summarized

36 Mann regards a voyage that lacks self-directed navigation as indicative of passive heroism: "In romance, when the hero (or heroine) puts out to sea, he is characteristically at its mercy, set adrift in a rudderless boat, allowing its winds and currents to set his course, challenged and thwarted by its storms"; Mann, "Sir Gawain and the Romance Hero," 107. A clearer example of this motif in the works of the Gawain-poet is found in Jonah's journey in the mysterious whale in Patience. On the motif of the rudderless boat, see also Cooper, The English Romance in Time, 106-36.

37 On Gawain's putative itinerary, see, for instance, Elliot, "Landscape and Geography," 105-17.

38 Prior, for instance, perceptively notes that the brief list of Gawain's battles “amounts to an anticlimactic dismissal" and adds that, instead, "Hardest of all his trials is Gawain's loneliness, and his lack of a refuge or shelter, even more his need for a place to attend Mass and the other holy offices of Christmas"; Prior, The Pearl Poet Revisited, 113. 
quickly in nine lines, and they function to remind us that the protagonist is a knight and does indeed engage in martial combat (715-23). In these lines, Gawain displays the aggressive or attacking aspect of fortitude by fighting some of the traditional enemies of knights. The poet concludes this description of Gawain's martial fortitude, and introduces his endurance, by pointing to the combination of virtue and grace that enables his success: "Nade he ben du3ty and dryze and Dry3tyn had serued, I Douteles he hade ben ded and dreped ful ofte" (724-25). The combination of courage, endurance, and proper religious intention is essential to Gawain's survival in the forest. "Dryze" here prepares the audience for the following description of Gawain's sufferings, and the pairing of $d u z t y$ (bold) and dryze (long-suffering) is an instance of the agere et pati topos that Georgia Ronan Crampton identifies, ${ }^{39}$ a topos that is found in the description of virtue prowesse/douztiness (fortitude) in the Book of Vices and Virtues: "[A good knight is revealed] bi moche doynge wip his honde in armes and bi moche woo suffrynge and endurynge" (163). The next ten lines, describing Gawain's journey through the frozen winter landscape, emphasize what Thomas of Chobham, William Peraldus, and Thomas Aquinas call the enduring aspects of fortitude:

For werre wrathed hym not so much pat wynter nas wors,

When pe colde cler water fro pe cloudez schadde

And fres er hit falle my3t to pe fale erpe.

Ner slayn wyth pe slete he sleped in his yrnes

Mo nyztez pen innoghe, in naked rokkez

Peras claterande fro pe crest pe colde borne rennez

And henged heze ouer his hede in hard iisseikkles.

Pus in peryl and payne and plytes ful harde

Bi contray caryez pis kny3t tyl Krystmasse Euen,

Alone.

(726-35)

Because he is a valiant knight, battle does not provide great difficulties for him. His greater enemies are the elements, which, like Gawain's fear, cannot be fought directly. Sleet nearly slays him; even though he sleeps in his armour, which provides barely adequate protection, he is vulnerable, and the icicles that form from the mountain stream threaten him from above. Finally, the poet emphasizes Gawain's isolation in line 735, in a one-word comment that highlights and intensifies the suffering he must endure.

39 Crampton, The Condition of Creatures, 1-44. See Middle English Dictionary s.v. doughtī and drī (e. 
Eventually, Gawain approaches an impasse, which is resolved supernaturally. He has been travelling for nearly two months, and even as his deadline approaches, he still has no idea where to find the Green Chapel; furthermore, it is Christmas Eve, and Gawain desires a place to attend Christmas mass. He is lost and weary and, fearing that he will miss the celebration of the Feast of the Nativity, he prays to Christ and Mary for help (748-55); this is the only activity available to him in a situation in which he is unable to advance his quest through his own direct action. The poet takes special care to make clear the connection between Gawain's prayer and the appearance of the castle: "Nade he sayned hymself, segge, bot prye / Er he wat3 war in pe wod of a won in a mote" (763-64). Helen Cooper dismisses the possibility that the appearance of Hautdesert is a miracle, because "it turns out to be the site of Gawain's temptation." 40 His immediate need, however, is for lodging and religious ritual, and the appearance of the castle facilitates both of these. Furthermore, in spite of the fact that Gawain feels tempted by the lady's seduction, as lines 1768-69 suggest, he is under the protection of the Virgin. In stories of heroic virtue, providence conventionally brings protagonists to the place of their testing and grants them the grace to endure the temptations that prove their virtue; for instance, God provides Saint Antony with both lodging in the wilderness, the traditional abode of demons, and the fortitude to endure the demonic attacks. The Green Knight's earlier instruction to ask people about him and the location of the Green Chapel actually fails to bring Gawain to his destination; instead, he arrives there by the action of grace in the midst of symbolic powerlessness, in a mysterious manner similar to that which brings the rudderless boat to shore.

In essence, the concept of impasse defines Gawain's quest, and the proper restraint of his emotions is essential to the negotiation of the various obstacles he encounters. Because of the nature of his agreement with the Green Knight, the quest consists primarily of Gawain's preparation for death. According to the rules of conduct to which he subscribes, Gawain must honour his promise to find the Green Knight and allow himself to be beheaded. His desire to manifest virtue thus makes his death necessary, yet the Gawain-poet emphasizes the volition involved in Gawain's endurance through the nature of his submission. Gawain must patiently submit his bare neck to the Green Knight's axe. First, he promises not to be angry with his executioner: "I schal gruch pe no grwe, for grem pat fallez; / Bot sty3 tel pe vpon on strok and I schal stonde stylle" (2251-52). He then staunchly resolves neither to show fear nor be afraid:

40 Cooper, “The Supernatural," 290. 
"And lette as he no3t dutte; / For drede he wolde not dare" (2257-58). Gawain must voluntarily restrain himself; he must use his knightly courage not to defend himself, but to accept death without physical combat. Anger and fear are his adversaries in this adventure. In order to foreground patient endurance, the poet dramatizes Gawain's internal struggle to will his behaviour in spite of the desire to preserve his life.

\section{Patient Endurance and the Passions}

As in discussions on patience that appear in the virtues and vices tradition, the relationship between the emotions and equanimity is a central concern in Sir Gawain and the Green Knight. Patience is often thought of as a calm endurance of hardships, an understanding that influences the poet's reconceptualization of the fifth beatitude in Patience: "Pay ar happen also pat con her hert stere, / For hores is pe heuen-ryche, as I er sayde" (27-28). The close association of patientia and the proper restraint of the irascible passions, such as anger and fear, both of which reside in the heart, is commonplace in patristic thought. For instance, in De patientia, Augustine contends that patience is "aequo animo mala tolerare" ([to] tolerate evils with an even mind). ${ }^{41}$ Also, Gregory the Great, in his Homiliae in Evangelia, defines the virtue as "aliena mala aequanimiter perpeti" (to endure external evils with equanimity). ${ }^{42}$ Ralph Hanna identifies these quotations as belonging to a group of "three statements [about patience that] are universally known [in the Middle Ages]." 43 Aquinas regards endurance as more difficult than aggression because of the need to restrain one's own actions while one is being goaded by fear or anger. As Rebecca Konyndyk De Young puts it, the function of fortitude is to "remove obstacles in our passions (or emotions) that withdraw us from what reason commands." 44 To this end it mediates between timor (fear), which requires "endurance," and audacia (daring), which inspires "aggression." Ultimately, Aquinas favours endurance because of its difficult relationship with the passions. De Young summarizes Aquinas's argument on the difficulty of endurance:

41 Augustine, De patientia, PL 611-26 (chap. 2.2).

42 Gregory, Homiliae in Evangelia, PL 1075-1312 (chap. 2.35.4).

43 Hanna, "Some Commonplaces," 68. In this foundational article, Hanna identifies four topics commonly associated with the virtue patientia, one of which concerns equanimity, the proper emotional state of the patient individual: "the central psychological act of the patient man is a voluntary indifference to external pain and a resulting inner equipoise"; Hanna, "Some Commonplaces," 77.

44 De Young, "Power Made Perfect in Weakness," 152. 
In acts of aggression (military heroism), there is a sense in which the agent still has some control over the situation: he acts because he believes he has sufficient power to establish or protect the good; to that extent, the agent still trusts his own power to overcome the threat. [...] In an act of endurance (martyrdom), the agent faces death upon pain of renouncing or betraying the truth, and, given the end, she is powerless to evade the threat: there is no way to escape or minimize the danger short of renouncing her end altogether, given that the power imbalance is tilted against her. Her fear signals that her control over the safeguarding or protecting of her own life is gone. The only means of resisting the evil is to stand fast and not give way while undergoing it. ${ }^{45}$

Whereas one who acts aggressively receives assistance from the passion daring (audacia, temeritas), one who manifests endurance receives no help from the passions and must rely on the power of ratio, reason, alone. Unfortunately, fear and rash aggression often overpower the properly ordered patient soul.

In Sir Gawain, the initial encounter with the Green Knight introduces the major emotions that are most closely connected to patient fortitude: fear and anger. The movement from fear to anger happens twice in the narrative: first, in the opening scene, when Arthur's fear is replaced by anger, and later, at the Green Chapel, when Gawain's emotional state shifts from fear to anger at having been duped. When the Green Knight challenges Arthur's court, the knights are initially too frightened to act; however, the anger that the Green Knight's insult arouses helps the knights forget their fear, and it is from this sense of outrage that Arthur acts. Although, as the poet remarks, the initial silence that greets the Green Knight may, at least for some of the knights, originate in courtesy and deference to the king (243-49), the silence after the Green Knight issues his particular challenge points to their collective fear, and forces Arthur to respond. The Green Knight addresses his challenge to all of the knights present: "runischly his rede yzen he reled aboute, / Bende his bresed brozez, blycande grene, / Wayued his berde for to wayte quoso wolde ryse" (304-306). When no one responds, not even the king (307-308), the Green Knight challenges the very identity of Arthur's house, and it is this identity that Arthur must maintain: "Now is pe reuel and pe renoun of pe Rounde Table / Ouerwalt wyth a worde of on wyzes speche, / For al dares for drede withoute dynt schewed!" (313-15). Here the Green Knight associates the failure to

45 De Young, "Power Made Perfect in Weakness," 163. In Aquinas, this discussion takes place in II.II.12324 (fortitude and martyrdom) and I.II.40-45 (the four emotions: hope, despair, fear, and daring). 
receive the adventure that he brings with a lack of fortitude. Courage unto death is what he demands, and the failure to manifest such virtue will result in the shaming of the entire court.

The revelation of the knights' fear arouses their anger, another emotion that is inappropriate in this context. After the challenger finishes his speech, Arthur and his knights respond involuntarily at first:

Pe blod schot for scham into his schyre face

And lere;

He wex as wroth as wynde;

So did alle pat per were.

(317-20)

Everyone feels angry and ashamed and, as Kevin Gustafson remarks, "The king's shame implicitly acknowledges the hit." ${ }^{46}$ At this point, all that the Green Knight requires from an opponent is a blow with an axe. Nicholls draws attention to Arthur's audacity in accepting the challenge; however, the king seems to have no other choice once the Green Knight has called into question the very legitimacy of Camelot's reputation as a stronghold of chivalry and a protector of the realm. Arthur responds with the righteous indignation of the insulted, yet while he must take up the challenge, an angry response is not necessary and, as Nicholls notes, "is impotent in the face of the Green Knight's impassivity." ${ }^{7}$ The Green Knight's arousal of the anger of Arthur and his court (309-15) has sought to let the king forget about the future blow from the visitor. While the Green Knight brings the knights' fear into the public space, Arthur's duty is to overcome its shameful influence and return it to the private space, as a pre-passion that does not direct the behaviour of the subject. ${ }^{48}$ However, since the challenge is not exactly a martial one, anger, which is useful for attacking but not for enduring, is not necessary. Instead, the Green Knight's complacency mocks Arthur's passionate response and draws acute attention to the inappropriateness of anger in this situation.

46 Gustafson, "Sir Gawain and the Green Knight," 622.

47 Nicholls, The Matter of Courtesy, 120.

48 A pre-passion is a potentially passionate movement of the soul that does not necessarily manifest itself in external action. For the currency of this stoic concept in various 11th-, 12th-, and 13th-century authors, such as Anselm of Laon, Anselm of Canterbury, Peter Abelard, Peter Lombard, Gilbert of Poitiers, Alan of Lille, Simon of Tournai, Peter of Capua, and William of Auxerre, see Knuuttila, Emotions in Ancient and Medieval Philosophy, chap. 3. While one cannot be sure whether the Gawainpoet was familiar with the terms antepassio or propassio, the concepts associated with them were commonplace. 
The manifestation of patience requires emotional restraint, and the poet depicts Gawain responding to the situation with equanimity, in spite of the fear that the knight's hesitancy to accept the initial challenge suggests; thus, Gawain has greater control of his passions than does the rest of the court. Many critics have noticed the contrast between Gawain's and Arthur's responses to the insult. ${ }^{49}$ While the Green Knight is indifferent and perhaps even a little bored, and while Gawain is both calm and deferential, Arthur, at this point, is rather haughty. ${ }^{50}$ Gawain does not respond directly to the insult; instead, he responds to the possibility of Arthur's decapitation. The narrator leaves the tension between Arthur's wrath and the Green Knight's equanimity at the bob in line 338; the wheel immediately following initiates the shift in focus from Arthur and the Green Knight to Gawain who, we are reminded, is sitting beside the queen, in a seat of honour:

Gawan, pat sate bi pe quene,

To pe kyng he can enclyne:

"I beseche now with sazez sene

pis melly mot be myne."

Gawain's request begins with the proper courtly protocol, even though the king, together with the rest of the court, is gripped with simultaneous fear and anger. His speech again recalls the idealized self-control of the servant described in lines 49-56 of Patience, who does not complain when his lord commands him to travel to Rome. Not only does Gawain willingly and consciously subject himself to almost certain death, but he delivers a carefully composed speech in which he maintains proper protocol and respect in asking for the boon of the quest (343-53). In his speech, Gawain asserts the king's authority over him while helping the king excuse himself from a potentially disastrous situation and while also soothing the king's anger. ${ }^{51} \mathrm{He}$

49 See Spearing, The Gawain-Poet, 183; Nicholls, The Matter of Courtesy, 121-24; Clein, Concepts of Chivalry, 83-84; and Walker, "The Green Knight's Challenge," 111-28.

50 The spirit of Gawain's intervention varies significantly from that which is found in the Caradoc episode of the First Continuation of Chrétien's Perceval, a text that Benson identifies as a possible source of SGGK; Benson, Art and Tradition, 16-38. Whereas Gawain is proud and aggressive in the putative source, he is cautious and deferential in $S G G K$; in addition, there is a sense of equanimity in the latter text which is not found in the former, where he also displays a form of heroic rashness. For a more recent comparison between SGGK and the Caradoc episode in the First Continuation of Chrétien's Perceval, see Putter, An Introduction to the Gawain-Poet, 41-43.

51 For more on the decorum of Gawain's intervention, see Walker, “The Green Knight's Challenge," 117. 
shows particular rhetorical skill by pointing to the potential breach of courtly propriety first by personalizing the sentiment, "For me pink hit not semly," and then by suggesting its universal nature: "as hit is sop knawen" (348). The effect is to remind the court, humbly yet unmistakably, of the necessity of courtly behaviour, which requires courage in the face of adversity. Gawain's self-control emphasizes his patience and reveals his appropriateness for the challenge. While necessity elects Gawain for the adventure, he voluntarily embraces it with decorum and finesse.

Although Gawain departs for his meeting expressing resignation, his fear becomes apparent as he draws nearer, both geographically and temporally, to the Green Chapel, and the poet uses this fear to foreshadow the limits of Gawain's patience, which are later revealed in his accepting the girdle. In Fitt I, he is conventionally heroic: although he hesitates with the rest of the court when the Green Knight issues his challenge, he does accept the challenge with perfect self-control. As the time for his departure approaches, the court mourns him as one about to die; Gawain, on the other hand, manifests an air of Boethian resignation:

Pe kny3t mad ay god chere

And sayde: "Quat schuld I wonde?

Of Destinés derf and dere

What may mon do bot fonde?"

(562-65)

Gawain reveals an emotional indifference to fate characteristic of the romance hero who must do what he can, and not hesitate on account of his fear of what destiny has in store. However, as his appointment at the Green Chapel approaches, the self-abandonment that he expresses at the beginning is put to the test, and he progressively experiences more and more apprehension. At first, he is simply anxious about arriving on time, but when his host at Hautdesert reassures him that the Green Chapel is nearby, his attention shifts to the possible outcome of the appointment, and he begins to fear death.

Gawain's fear of death is perfectly natural, yet the poet uses it to suggest the weakness that will result in his failure. What makes his prospective death particularly heroic is the fact that he must endure the stroke of the Green Knight's axe without recourse to any sort of retaliation: his martial energies must be restrained in order to uphold an ideal. He could, like Jonah in Patience, attempt to escape the transcendent demands of his calling, but instead he embraces the prospect of his death anxiously, yet determinedly. As Wendy Clein observes, "For the warrior who falls in battle, death brings the consolation of fame and glory; for the knight who must face his end 
passively, chivalric courage is likely to falter." ${ }^{2}$ What Clein does not address is the reason for this failure of nerve that knights experience when they face death outside of battle. In battle, a knight uses anger in order to overcome fear; however, when he faces death in a situation in which anger cannot be aroused, he must simply endure fear. Gawain's fear not only is natural, but also highlights his fortitude in his submission to the Green Knight's axe.

The poet gradually introduces Gawain's fear regarding the blow that he is to receive from the Green Knight and thereby gently prepares the audience for the knight's decision to accept the girdle, an act which signifies the loss of the hero's equanimity. The language used to describe Gawain's fear recalls that which the poet uses to discuss patience in Patience. In lines 1283-87 of Sir Gawain and the Green Knight, Gawain is so preoccupied with the blow that will strike him down that he is unable to attend to the beautiful lady as he would otherwise. Later, the narrator again points to Gawain's anxiety, but this time in even greater detail:

In dre3 droupyng of dreme draueled pat noble, As mon pat watz in mornyng of mony pro poztes, How pat Destiné schulde pat day dele hym his wyrde At pe Grene Chapel when he pe gome metes

And bihoues his buffet abide withoute debate more.

Gawain's dream betrays his inner struggle, which the narrative hints at only occasionally. The expression "pro po3tes" (1751) also appears in the singular in line 645, where it points to the steadfastness with which he derives his aggressive fortitude from the Five Joys of Mary. The Middle English Dictionary defines the adjective pro in line 1751 according to the second denotation, which includes "angry," "savage," and "severe." ${ }^{3}$ Because of his inability to resort to aggression to resolve the situation, Gawain's "pro pozt" is here not concerned with gaining strength from the image of the Virgin in order to increase his courage in battle, as it is in line 645. Furthermore,

52 Clein, Concepts of Chivalry, 83. Clein proves this point by commenting on wills of 14th-century knights and the anti-chivalric tradition. According to Clein, knights who contemplate their deaths in an "unheroic context" do not receive encouragement from the warrior ethos; instead, they "adopt the moralist contempt for the things of this world." Thus, she concludes, "The rejections of the military trappings and chivalric values indicate a flaw in the fourteenth-century synthesis of chivalry"; Clein, Concepts of Chivalry, 71.

53 Middle English Dictionary s.v. pro. 
the language of this passage is notably similar to that in the introduction of Patience: "Pen is better to abyde pe bur vmbestoundes / Pen ay prow forth my pro, paz me pynk ylle" (7-8). Gawain's "pro poztes" challenge his ability to "abide" the "buffet," just as the "pro" and "pynk[ande] ylle" of the narrator of Patience make him desire not to "abyde pe bur." That Gawain must endure what "Destiné" appoints "withoute debate more" again recalls the ethos of Patience, where the narrator asks, " 3 if me be dy3t a destyné due to haue, / What dowes me pe dedayn, oper dispit make?” (49-50). While, in light of the patience that is required of him, Gawain's anxiety becomes more conspicuous each day, the pleasure of the beautiful lady's company provides a temporary and transformative relief from the mortal fear that he faces. His emotional states cause him both suffering and pleasure, yet, until this point, they do not cause him to act inappropriately or to reveal his fear to others; his equanimity, which is an essential component of his patience, still remains intact, even if his wavering between fear and desire prepares him for a failure of virtue.

When Gawain accepts the girdle from Lady Bertilak, which he does primarily because it offers him the possibility of survival, ${ }^{54}$ fear alone does not upset his reason; rather, hope assists in the act. Or one might more accurately say that the hope of survival increases Gawain's fear and causes his failure to endure perfectly. Hope here is not the theological virtue, but one of the four primary passions. ${ }^{55}$ Aquinas, echoing Aristotle, observes that if one cannot prevent a possible evil from occurring, "hope is shattered and consequently so is fear." 56 Since Gawain might survive, hope (and thus fear) has greater strength. The knight manifests exemplary patience until he is tempted by the possibility of survival. W. R. J. Barron, using Aquinas's observations on the power

54 In lines 1855-58, Gawain considers accepting the token only when the lady reveals its magical property; see, for instance, Howard, The Three Temptations, 225 and 236-37. As Howard notes in the latter passage, Gawain's change of mind is not immediate; instead, he considers how the acceptance of the girdle would be justified by its ability to save his life. As a result of this realization, he "poled hir to speke" (1859). Although the word pole is necessary for the alliterative quality of the line, it also reminds the audience of Gawain's relationship to suffering; his suffering her to speak is an appropriate form of suffering for a courtly knight, yet his motivation for doing so is his desire to live.

55 See, for example, Boethius's Consolation of Philosophy I.vii.27 and Aquinas's Summa I.II.40.2. While I maintain that fear and hope are the main passions that overthrow Gawain's rational faculty, Whiteford offers the insightful observation that Gawain's acceptance of the girdle is facilitated by his being too distracted to properly exercise his vis aestimativa, the faculty of his mind that evaluates sensory information; Whiteford, "Rereading Gawain's Five Wits," 231-32.

56 Aquinas, Summa, I.II.42.6. 
of the passions to overcome reason and thereby cause one to mistake an evil for an apparent good, hypothesizes that Gawain accepts the girdle because, being "oppressed by fear of death, he was so overwhelmed by the prospect of escape offered by the girdle that he was momentarily incapable of appreciating the significance of accepting it, unable to weigh its value against that of the pentangle." ${ }^{77}$ However, if Gawain is only "momentarily" unable to appreciate the ethical implications of accepting the girdle, then why does he wear it to his meeting with the Green Knight? In fact, the acceptance of the girdle does not contradict any of the virtues that appear in the pentangle. As I have argued above, it violates Gawain's patient endurance, a virtue whose presence among the pentangle virtues is only hinted at, but which is nonetheless required for maintaining the integrity of all of Gawain's virtues. Until this point, Gawain has done nothing that he will later regret; however, he compromises his integrity when he accepts the girdle, and he later vows to bear this guilt until he dies. Gawain's failure is not simply a result of his fear of death or dishonour; his equanimity is not lost by lust or fear exactly, but it is set off balance by the hope of survival.

The possibility of survival perhaps provides Gawain with a small measure of relief, but it does not ultimately mitigate his fear. Instead, his fear accentuates the determination with which he undertakes his task and draws attention to the great difficulty of enduring fortitude, which, unlike aggression, cannot be strengthened by the passions. The narrator emphasizes Gawain's fear during the night and during the morning on which he sets out, and this fear points to his incomplete trust in the girdle (1991-92, 2006-2007). ${ }^{58}$ Gawain's fear becomes even more palpable as he draws nearer to the Green Chapel. When the guide attempts to frighten Gawain away from his meeting with the Green Knight, the hero's response is gracious — he thanks the guide for his concern and expresses his trust in the guide's discretion, yet the participle gruchyng (2126) describes the manner of his speech: Gawain is annoyed. The indignant tone of his reply may result simply from the inappropriateness of the guide's

57 Barron, Trawthe and Treason, 127. Clein notes that the exchange of winnings game does not seem nearly as serious as the beheading game; Clein, Concepts of Chivalry, 114. However, the ending suggests simultaneously that virtue is found in details, and that the details are not as important as major possible failures such as flight or adultery.

58 Gawain's confession, through which he prepares for death, also implies his incomplete trust in the girdle (1876-84). With respect to the apparent incompleteness of Gawain's confession and reconciliation, Andrew and Waldron provide the plausible explanation that Gawain fully recognizes the seriousness of his possession of the girdle only in retrospect; Andrew and Waldron, eds., The Poems of the Pearl Manuscript, 275, n. on 11. 1876-84. 
suggestion; however, the knight reveals that fear, to a certain extent, influences his behaviour during the journey, by his reminding himself, after the guide has left, of his obedience to God:

\author{
"Bi Goddez Self," quop Gawayn, \\ "I wyl nauper grete ne grone; \\ To Goddez wylle I am ful bayn \\ And to Hym I haf me tone."
}

(2156-59)

This passage yet again suggests the classical notion of patience that regards the virtue as consisting of the endurance of adverse fortune without complaint, a definition that characterizes the narrator's understanding of the virtue in Patience. ${ }^{59}$ By refusing to express the extent of his mental suffering, Gawain reveals, on the one hand, that he is plagued by fear and, on the other hand, that virtue requires one to remain silent about one's suffering; patience here consists not only of enduring painful emotions but of refusing to allow oneself even the comfort of manifesting, of expressing, of enacting, that is, of allowing one's behaviour to be influenced in any conspicuous way by the passion that afflicts one's soul. Nevertheless, the representation of patience requires that suffering be expressed somehow in order to reveal the difficulty of manifesting the virtue. Thus, Gawain's emotional suffering points to his belief that he might yet die at the Green Chapel.

Gawain still experiences great fear in spite of the talisman, yet he does not succumb to the sort of hope of survival that the guide offers, the result of which would unambiguously jeopardize his integrity. While Gawain's courage is compromised by the girdle and while his fear seems to persist because of his doubt concerning the girdle's power, there is no reason to suspect that his courage would have failed him without it. After all, his intention to keep his appointment at the Green Chapel never changes. His possession of the girdle does not provide him with the necessary fortitude to attend his appointment at the Green Chapel. Instead, the talisman points to the power of the fear that he tries to keep hidden and the difficulty of quietly accepting death when the possibility of survival is offered.

Gawain's emotions, and consequent behaviour, during the meeting at the Green Chapel dramatize the difficulty of patient endurance and the great relief the knight finds in the possibility for martial aggression. The emotional tension that Gawain

59 See Hanna, “Some Commonplaces," 73-74. 
has been experiencing during his stay at Hautdesert uncoils rapidly during the scene in the Green Chapel. Gawain's flinching after the first feint points to the difficulty of his trial, and his stillness during the second feint, as the Green Knight remarks (229698), points to his great fortitude. Furthermore, that Gawain rises quickly to defend himself after the third feint reveals the great courage he has been exercising through the regulation of his emotions:

And quen pe burne sez pe blode blenk on pe snawe,

He sprit forth spenne-fote more pen a spere lenpe,

Neuer syn pat he watz barne borne of his moder

Watz he neuer in pis worlde wyze half so blype.

(2315-21)

According to Mann, this scene indicates that Gawain's passivity requires just as much energy as activity. ${ }^{60}$ To be sure, Gawain unleashes a great deal of emotional energy after a long period of rigid self-control. He is eager to fight the Green Knight, and his joy caused by his surviving the ordeal mobilizes his aggressive posture. Instead of having to continue to restrain his passions in order to endure death without the possibility of retaliation, he can now channel their energy into his aggressive stance and, if need be, into battle. This dramatic transformation of the knight's emotional state draws even more attention to the intense difficulty of the internal struggle that he has experienced.

After Bertilak debriefs Gawain by revealing himself and Morgan's plot, Gawain responds to his humiliation not with patience and humility, but with anger. The former upholds Gawain's reputation as a "Bolde burne" (2338); the latter, however, because of his recognition of his failure to manifest perfect enduring fortitude, chastises himself, and shame replaces his passionate bravado. The Green Knight also tells him to "be not so gryndel" (2338), a phrase that recalls God's chastising Jonah for his impatience at the conclusion of Patience (524), yet the focus of Gawain's anger shifts from his cowarddyse and couetyse, the vices that caused him to fail, to the girdle, the physical manifestation of his failure, which he aggressively attempts to return to the Green Knight ("Penne he ka3t to pe knot and pe kest lawsez, / Brayde bropely pe belt to pe burne seluen," 2376-77). His acceptance of the girdle is an act of cowardice, inasmuch as he has compromised his integrity by failing to fulfil his agreement in the exchange of winnings in order to save his life. While one can assume that Gawain's

60 Mann, "Sir Gawain and the Romance Hero," 111. 
fear would not have prevented him from submitting to the Green Knight's axe, he has still been willing to sacrifice his integrity in a smaller matter to preserve his life, an act that leads him to accuse himself of "cowarddyse and couetyse bope" (2374). ${ }^{61}$ After he seems to have regained control of his anger, he blames the alleged power of women to beguile men (2414-28) in a speech that sounds more like a rash attempt to rationalize his failure than a conclusive analysis of its cause. Gawain's shame originates in his submission to fear, just as Arthur's anger at the Green Knight's insult suggests his need to save face after his, and his court's, initial hesitancy to participate in the beheading game.

When Gawain regains control of his passions, he resolves to identify the girdle as a reminder of the weakness of the flesh that has caused his fortitude to be imperfect, and he thereby reveals his determination to assimilate his experience. ${ }^{62}$ Gawain invests

61 As Burrow perceptively argues, the Green Knight's and Gawain's responses to the infraction present the audience with two different perspectives on the protagonist's desire to preserve his life. He contends that Bertilak is right about the way in which Gawain's fear mitigates his sin, since, as Aquinas observes, "passion diminishes sin," and Gawain is right to accuse himself of cowardice, since his acceptance of the girdle was not involuntary. Burrow concludes, "the single passion, fear, gives valid occasion both for extenuation ('love of life') and for blame ('cowardice')"; Burrow, A Reading of Sir Gawain and the Green Knight, 135.

62 As critics commonly note, and as lines 2434-35 suggest, Gawain keeps the girdle to inspire him to lament "Pe faut and pe fayntyse of pe flesche crabbed" (2435). Burrow, Howard, Barron, and Clein all comment that Gawain's wearing of the girdle points to the hero's desire to be mindful of his failure, which, he discerns, originates in the weakness of the flesh, revealed here through his having compromised his ideals in order to save his life; see Burrow, A Reading, 150-52; Howard, The Three Temptations, 228-29; Barron, Trawthe and Treason, 133-35; and Clein, Concepts of Chivalry, 124-25. Champion reads a theological controversy in the symbolism of the girdle which, he argues, serves as a "constant reminder of the virulent dangers of Pelagian self-determination"; Champion, "Grace versus Merit," 424. And Johnson contends that the girdle, as a sign, "points the way to true perfection through penance"; Johnson, The Voice of the Gawain-Poet, 92. Spearing argues that Gawain's decision to wear the girdle subtly suggests his pride: while the girdle is meant to remind him of his weakness, its public display gently points to the hero's human egoism; Spearing, The Gawain-Poet, 230. More recent critics emphasize the ambiguity of the girdle as a sign. Prior, for instance, regards the girdle, unlike the pentangle, as both an ambiguous signum and an actual res; the understanding of Gawain's signs, like the depiction of Gawain himself, moves from inherent perfection to ambiguous signification; Prior, The Pearl Poet Revisited, 122-23. Both Heng and Boyd examine Gawain's donning of the girdle as acknowledging a perceived threat to, and a reassertion of, masculinity; Heng, "Feminine Knots," and Boyd, "Sodomy, Misogyny, and Displacement," 89-90 and 104-105. While the significance of the girdle does indeed change according to the circumstances of each scene in which it is discussed and the characters who are interpreting it, I am primarily concerned with Gawain's imbuing of the girdle with symbolic meaning in light of his failure to endure perfectly. 
the girdle with an appropriate signification; it is to remind him of the failure resulting from the incompleteness of his fortitude: "quen pryde schal me pryk for prowes of armes, / Pe loke to pis luf-lace schal lepe my hert" (2437-38). The girdle here has a complementary function to that of the image of the Virgin on the inside of his shield: while the latter helps him fight in spite of his fear, the former encourages him to remain calm in spite of his pride and anger. The effect of the verb le then ("to heal," or, here, "to humble") on the proud and aggressive heart recalls the healing effect of patience on the embittered heart described in the initial lines of Patience: "When heuy herttes ben hurt wyth hepyng oper elles, / Suffraunce may aswagen hem and pe swelme lepe" (2-3). Gawain formerly perceived himself as having mastered the passions, the proof of which was to be found in his patient enduring of death without choosing to retaliate. Yet, as the Green Knight clarifies for him, Gawain has failed to endure perfectly, and the anger and despondency he suffers after his humiliation confirm the power of his passionate nature. In the future, when he is about to act aggressively, he will look at the girdle and be reminded of his failure to suffer without fault.

The response of Arthur and his court to Gawain's failure seems ambiguous but intends to acknowledge the collective failure of Camelot. While recounting his adventure, Gawain relives the shame that he experienced when he became aware of his failure. He states that his act can never be forgotten and that his choosing to wear the girdle points to the irrevocability of his failure. The immediate jocular response of Arthur and the other knights seems to belittle Gawain's failure, yet they agree to honour Gawain and the girdle, and their decision to do so cannot be reduced to simple playfulness. Instead, the poet uses this episode to point to the collective integration of Gawain's experience. The poet tells us that the intention of the king is to "comfort" the knight (2513). By collectively deciding to wear green baldrics, Arthur and his knights symbolically acknowledge their shared responsibility in the shortcoming that Gawain manifests. None of the other knights, including the king himself, has displayed as much enduring fortitude as Gawain has. Thus, the poet implies that Gawain's failure is not just his own but that of the Round Table and the idealism that it represents.

In Sir Gawain, the Green Knight's challenge provides an exploration of the boundaries of heroic patience through the protagonist's capacity for suffering and his determination to complete his quest in spite of fear. For both Aquinas and the Gawain-poet, endurance is the essence of the virtue fortitude and, as such, it is more difficult than aggression. The theme of patient endurance in Sir Gawain and the Green Knight 
emerges gradually during the narrative: the initial description of Gawain's virtues includes only a subtle reference to enduring fortitude, yet the poet reveals the conventions of the virtue in Gawain's acceptance of the adventure, in his journey to and arrival at Hautdesert, and, most importantly, in the challenge itself, which ultimately requires Gawain to render himself absolutely vulnerable to the Green Knight's axe. Gawain's repeated condemnation of his own alleged cowardice particularly draws attention to the failure of enduring fortitude, since he has not failed with respect to aggression but with respect to endurance. While Gawain does manifest an impressive degree of patient fortitude in his determination to fulfil the terms of his agreement with the Green Knight, the poet depicts the power of the passions to overcome patient fortitude, particularly since the virtue cannot fortify itself with a passion, as aggressive fortitude can with anger. Endurance does not require just as much energy as attacking, as Jill Mann has suggested, but it requires even more in its battle to control the passions.

By considering the poet's portrayal of Gawain and his adventure within the context of the medieval patience discussions, one can discern the tradition of patience that unifies the poem's focus on fear, anger, suffering, and endurance. By framing the exploration of the virtue within the context of secular romance, the poet salvages the knight's heroism; such a failure of endurance in the context of religious narrative could only result in the loss of heroic status. Thus, the poem can focus on the difficulty of attaining to the virtue instead of the failure of the knight, a focus that would risk being lost in a religious context. In the larger setting of Cotton Nero A.x, both a knight, Gawain, and a prophet, Jonah, fail to manifest perfect enduring fortitude, which is the domain of martyrs. Like Jonah, Gawain is constrained to act according to his identity, and he manifests patience through submitting to an agreement that ultimately threatens his life. While he at first hesitates to embrace the adventure, he does consent eventually and faces the threat of death with greater heroic poise than Jonah does when he first receives the call to preach in Nineveh; nevertheless, like that of the prophet, the knight's courage does indeed fail him. Still, Gawain manifests enduring fortitude in his determination to meet the Green Knight's challenge, and although he does not complete his quest in an ideal fashion by approaching the possibility of death without altering his behaviour because of fear, his determination to endure the blow of the Green Knight's axe earns him the respect of his adversary. Gawain's failure inspires him to regard the girdle as a symbol of the difficulty of patient endurance, and this symbol is later shared by all of the knights of Camelot.

University of Saskatchewan 


\section{Bibliography}

Aers, David. Community, Gender, and Individual Identity: English Writing 1360-1430. London: Routledge, 1988.

Anderson, J. J., ed. Sir Gawain and the Green Knight, Pearl, Cleanness, Patience. London: J. M. Dent, 1996.

—. "The Three Judgments and the Ethos of Chivalry in Sir Gawain and the Green Knight." Chaucer Review 24, no. 4 (1990): 337-55.

Andrew, Malcolm, and Ronald Waldron, eds. The Poems of the Pearl Manuscript: Pearl, Cleanness, Patience, Sir Gawain and the Green Knight. 5th ed. Exeter: Univ. of Exeter Press, 2007.

Aquinas, St Thomas. Summa Theologioe: Latin Text and English Translation, Introductions, Notes, Appendices, and Glossaries. 61 vols. Cambridge: Blackfriars, 1964-1981.

Augustine. De patientia. Ed. J. P. Migne. Patrologia Latina 40:611-26.

Barron, W. R. J. Trawthe and Treason: The Sin of Gawain Reconsidered. Manchester: Manchester Univ. Press, 1980.

Bell, David N. The Libraries of the Cistercians, Gilbertines and Premonstratensians. London: British Library, 1992.

Benson, Larry D. Art and Tradition in Sir Gawain and the Green Knight. New Brunswick, N.J.: Rutgers Univ. Press, 1965.

Bloomfield, Morton W. "The Problem of the Hero in the Later Medieval Period." In Concepts of the Hero in the Middle Ages and the Renaissance, edited by Norman T. Burns and Christopher J. Reagan, 27-48. Albany, N.Y.: State Univ. of New York Press, 1975.

—, Bertrand-Georges Guvot, O.P., Donald R. Howard, and Thyra B. Kabealo. Incipits of Latin Works on the Virtues and Vices, 1100-1500 A.D., Including a Section of Incipits of Works on the Pater Noster. Mediaeval Academy of America Publications 88. Cambridge, Mass.: Mediaeval Academy of America, 1979.

Boyd, David L. "Sodomy, Misogyny, and Displacement: Occluding Queer Desire in Sir Gawain and the Green Knight." Arthuriana 8, no. 2 (1998): 77-113.

Burrow, J. A. A Reading of Sir Gawain and the Green Knight. London: Routledge \& Kegan Paul, 1965.

- Ricardian Poetry: Chaucer, Gower, Langland, and the Gawain-Poet. London: Routledge, 1971.

Champion, Larry S. "Grace versus Merit in Sir Gawain and the Green Knight." Modern Language Quarterly 28, no. 4 (1967): 413-25.

Clein, Wendy. Concepts of Chivalry in Sir Gawain and the Green Knight. Norman: Pilgrim Books, 1987.

Cooper, Helen. The English Romance in Time: Transforming Motifs from Geoffrey of Monmouth to the Death of Shakespeare. Oxford: Oxford Univ. Press, 2004.

—. "The Supernatural." In A Companion to the Gawain-Poet, edited by Derek Brewer and Jonathan Gibson, 277-91. Cambridge: D. S. Brewer, 1997. 
Crampton, Georgia Ronan. The Condition of Creatures: Suffering and Action in Chaucer and Spenser. New Haven, Conn.: Yale Univ. Press, 1974.

Davenport, W. A. The Art of the Gawain-Poet. London: Athlone Press, 1978.

De Young, Rebecca Konyndyk. "Power Made Perfect in Weakness: Aquinas's Transformation of the Virtue of Courage." Medieval Philosophy and Theology 11 (2003): 147-80.

Elliot, Ralph. "Landscape and Geography." In A Companion to the Gawain-Poet, edited by Derek Brewer and Jonathan Gibson, 105-17. Cambridge: D. S. Brewer, 1997.

Francis, W. Nelson, ed. The Book of Vices and Virtues. EETS o.s. 217. London: Oxford Univ. Press, 1942.

Gregory the Great. Homiliae in Evangelia. Ed. J. P. Migne. Patrologia Latina 76:1075-1312.

Gustafson, Kevin. "Sir Gawain and the Green Knight." In A Companion to Medieval English Literature and Culture c.1350 - c.1500, edited by Peter Brown, 619-33. Oxford: Blackwell, 2007.

Hanna, Ralph, III. "Some Commonplaces of Late Medieval Patience Discussions: An Introduction." In The Triumph of Patience: Medieval and Renaissance Studies, edited by Gerald J. Schiffhorst, 65-87. Orlando: Univ. Presses of Florida, 1978.

Hark, Ina Rae. “Gawain’s Passive Quest.” Comitatus 5 (1974): 1-13.

Heng, Geraldine. "Feminine Knots and the Other Sir Gawain and the Green Knight." PMLA 106, no. 3 (1991): 500-14.

Howard, Donald R. The Three Temptations: Medieval Man in Search of the World. Princeton: Princeton Univ. Press, 1966.

Humphreys, K. W. The Friars' Libraries. London: The British Library, 1990.

Johnson, Lynn Staley. The Voice of the Gawain-Poet. Madison: Univ. of Wisconsin Press, 1984.

Knuuttila, Simo. Emotions in Ancient and Medieval Philosophy. Oxford: Clarendon Press, 2004.

Longo, Joseph A. “Sir Gawain and the Green Knight: The Christian Quest for Perfection.” Nottingham Mediaeval Studies 11 (1967): 57-85.

Mann, Jill. "Sir Gawain and the Romance Hero." In Heroes and Heroines in Medieval English Literature: A Festschrift Presented to André Crépin on the Occasion of his Sixty-Fifth Birthday, edited by Leo Carruthers, 105-17. Cambridge: D. S. Brewer, 1994.

McAlindon, T. "Magic, Fate, and Providence in Medieval Narrative and Sir Gawain and the Green Knight.” Review of English Studies n.s. 16 (1965): 121-39.

Middle English Dictionary. Ed. Hans Kurath, Sherman M.Kuhn et al. Ann Arbor, Mich.: Univ. of Michigan Press, 1952-2001. Electronic version available at <http://quod.lib.umich .edu $/ \mathrm{m} / \mathrm{med} />$.

Morgan, Gerald. "The Significance of the Pentangle Symbolism in 'Sir Gawain and the Green Knight." Modern Language Review 74, no. 4 (1979): 769-90.

Nicholls, Jonathan. The Matter of Courtesy: Medieval Courtesy Books and the Gawain-Poet. Woodbridge: D. S. Brewer, 1985. 
Peraldus, William. Summa virtutum ac vitiorum Guilhelmi Peraldi. Paris: Jehan Frellon, 1512. Plummer, John. "Signifying the Self: Language and Identity in Sir Gawain and the Green Knight." In Text and Matter: New Critical Perspectives of the Pearl-Poet, edited by Robert J. Blanch, Miriam Youngerman Miller, and Julian N. Wasserman, 195-212. Troy, N.Y.: Whitston, 1991.

Prior, Sandra Pierson. The Pearl Poet Revisited. New York: Twayne, 1994.

Putter, Ad. An Introduction to the Gawain-Poet. New York: Longman, 1996.

Schiffhorst, Gerald J. "Patience Inventory." In The Triumph of Patience: Medieval and Renaissance Studies, edited by Gerald J. Schiffhorst, 36-64. Orlando: Univ. Presses of Florida, 1978.

Sharpe, R., J. P. Carley, R. M. Thomson, and A. G. Watson. English Benedictine Libraries: The Shorter Catalogues. London: The British Library, 1996.

Silverstein, Theodore. "Sir Gawain in a Dilemma, or Keeping Faith with Marcus Tullius Cicero." Modern Philology 75, no. 1 (1977): 1-17.

Spearing, A. C. The Gawain-Poet: A Critical Study. Cambridge: Cambridge Univ. Press, 1970. Spendal, R. J. "The Fifth Pentad in 'Sir Gawain and the Green Knight."” Notes and Queries 23, no. 4 (1976): 147-48.

Thomas of Chobham. Summa de commendatione virtutum et extirpatione vitiorum. Corpus Christianorum: Continuatio Mediaevalis 82B. Ed. Franco Morenzoni. Turnhout: Brepols, 1997.

Twomey, Michael W. "Morgan le Fay at Hautdesert." In On Arthurian Women: Essays in Memory of Maureen Fries, edited by Bonnie Wheeler and Fiona Tolhurst, 103-19. Dallas, Tex.: Scriptorium Press, 2001.

Walker, Greg. "The Green Knight's Challenge: Heroism and Courtliness in Fitt I of Sir Gawain and the Green Knight." Chaucer Review 32, no. 2 (1997): 111-28.

Wenzel, Siegfried, ed. Summa virtutum de remediis anime. Athens, Ga.: Univ. of Georgia Press, 1984.

Whiteford, Peter. “Rereading Gawain’s Five Wits.” Medium Ævum 73, no. 2 (2004): 225-34. 